Article

\title{
Effects of Ti, Ni, and Dual Ti/Ni Plasma Immersion Ion Implantation on the Corrosion and Wear Properties of Magnesium Alloy
}

\author{
Jun Dai ${ }^{1,2, *}$, Zheng Liu ${ }^{3, *}$, Banglong Yu ${ }^{1}$, Qingdong Ruan ${ }^{2}$ and Paul K. Chu ${ }^{2}$ (I) \\ 1 School of Automotive Engineering, Changshu Institute of Technology, Changshu 215500, China; \\ yubanglong@163.com \\ 2 Department of Physics, Department of Materials Science and Engineering and Department of Biomedical \\ Engineering, City University of Hong Kong, Kowloon 999077, China; qingruan@cityu.edu.hk (Q.R.); \\ paul.chu@cityu.edu.hk (P.K.C.) \\ 3 School of Mechanical Engineering, Guilin University of Aerospace Technology, Guilin 541004, China \\ * Correspondence: jdaijs@163.com (J.D.); liuzheng@guat.edu.cn (Z.L.)
}

Received: 4 March 2020; Accepted: 23 March 2020; Published: 26 March 2020

check for updates

\begin{abstract}
Ti}, \mathrm{Ni}$, and Ti/Ni plasma immersion ion implantation is carried out on the AM60 magnesium alloy with a $6 \times 10^{16}$ ions $/ \mathrm{cm}^{2}$ fluence and energy of $35 \mathrm{keV}$. The corrosion and wear properties of the ion-implanted samples are determined systematically by X-ray photoelectron spectroscopy, $\mathrm{X}$-ray diffraction, scanning electron microscopy, electrochemical methods and wear tests. A Ni-rich layer composed of $\alpha-\mathrm{Mg}, \mathrm{Ni}_{2} \mathrm{O}_{3}$, and $\mathrm{NiTi}_{2}$ is formed on the surface after dual Ti/Ni ion implantation, and the ion implantation range is approximately $300 \mathrm{~nm}$. The corrosion resistance of the Ni- and Ti/Ni-implanted AM60 samples is significantly reduced in the $3.5 \% \mathrm{NaCl}$ solution. However, $\mathrm{NiTi}_{2}$ does not adhere well to the grinding ring during the wear test due to the bonding properties, and the sample implanted with both $\mathrm{Ti}$ and $\mathrm{Ni}$ shows the best wear resistance.
\end{abstract}

Keywords: magnesium alloy; plasma ion implantation; Ti/Ni coatings; corrosion resistance; wear resistance

\section{Introduction}

Magnesium alloys are widely used in many fields because of their light weight, good damping capacity, and recycling potential [1-3]. Unfortunately, the corrosion resistance of magnesium alloys in many engineering applications is insufficient $[4,5]$ and methods such as micro-arc oxidation [6,7], laser cladding [8,9], plasma electrolytic oxidation [10,11] and ion implantation [12-15] have been proposed to improve the corrosion properties. For example, $\mathrm{Zn}$ [16,17], $\mathrm{Zr}$ [18], $\mathrm{Nd}$ [19], $\mathrm{C}_{2} \mathrm{H}_{2}$ [20] and $\mathrm{Si}$ [21] ion implantations have been conducted on $\mathrm{Mg}$ alloys to improve the surface properties [17,22].

Some duplex coatings such as Ti/N [23,24], Al/N [25], $\mathrm{Zr} / \mathrm{N}$ [26] and $\mathrm{Cr} / \mathrm{O}$ [27] have also been investigated. AZ31 Mg Alloy samples with $\mathrm{N}$ and Ti duplex ion implantation possess a significantly improved corrosion resistance. Dual $\mathrm{Zr} / \mathrm{N}$ plasma ion implantation forms a $53 \mathrm{~nm}$ thick $\mathrm{Zr}$ rich layer and a $66 \mathrm{~nm}$ thick $\mathrm{N}$ rich layer on the WE43 Mg alloy. The corrosion resistance of the Mg alloy sample is improved following dual ion implantation.

It is difficult for the composition of single-ion implantation to meet the various requirements in harsh environments. There are few studies on the interaction between ions after duplex ion implantation. Metal ions and non-metal ions are usually used together to improve the properties of Mg alloys. In spite of recent advances, dual metal ion implantation on AM60 magnesium alloy has seldom been performed with successful outcomes. 
In this work, AM60 magnesium alloy is implanted with $\mathrm{Ti}, \mathrm{Ni}$, as well $\mathrm{Ti} / \mathrm{Ni}$. The corrosion and wear properties of the various samples were studied in detail and the mechanism was investigated with the aid of first-principles calculation.

\section{Experimental Details and Theoretical Calculation}

AM60 magnesium alloy plates with dimensions of $15 \mathrm{~mm} \times 15 \mathrm{~mm} \times 2 \mathrm{~mm}$ were ground with $\mathrm{SiC}$ paper up to 2000\# and ultrasonically cleaned in alcohol for $5 \mathrm{~min}$. Plasma immersion ion implantation was carried out on the PI-80A plasma immersion ion implanter in City University of Hong Kong's Plasma Laboratory. The base pressure in the vacuum chamber was $2 \times 10^{-3} \mathrm{~Pa}$ and $\mathrm{Ti} / \mathrm{Ni}$ ion implantation was performed at an accelerating voltage of $35 \mathrm{keV}$ with a fluence of $6 \times 10^{16}$ ions $/ \mathrm{cm}^{2}$. Sample "Ti" was implanted with Ti only, sample "Ni" with $\mathrm{Ni}$ only, and sample "TiNi" with $\mathrm{Ti}$ and then Ni. To compare results, the properties of the un-implanted base metal AM60 (BM) were determined under the same conditions.

To determine the elemental depth profile and chemical states of the implanted samples, an X-ray photoelectron spectroscopy (XPS, PHI-5000 Versaprobe, Kanagawa, Japan) was completed with Al $\mathrm{K}_{\alpha}$ irradiation at a sputtering rate of approximately $10 \mathrm{~nm} / \mathrm{min}$. The sputtering rate was estimated to be approximately $10 \mathrm{~nm} / \mathrm{min}$ based on the analysis of a standard $\mathrm{SiO}_{2}$ film under the same conditions. The structure was analyzed by X-ray diffraction on the D2 Phaser X-ray diffractometer (XRD) (BRUKER, Karlsruhe, Germany) with $\mathrm{Cu} \mathrm{K} \alpha$ radiation. Immersion corrosion tests were carried out to evaluate the corrosion properties in $3.5 \% \mathrm{NaCl}$ and after immersion for $24 \mathrm{~h}$, the samples were observed by scanning electron microscopy (SEM, ZEISS SIGMA500, Dresden, Germany) and analyzed by XRD.

The wear resistance performance was tested by a ball-on-disc wear tester (CETR UMT-2, CA, USA) at a relative humidity of $35 \%$ and temperature of $25^{\circ} \mathrm{C}$ using a $\mathrm{Si}_{3} \mathrm{~N}_{4}$ ball with a radius of $1.5 \mathrm{~mm}$. The sliding distance and rotation rate were $3 \mathrm{~mm}$ and $200 \mathrm{r} / \mathrm{min}$, respectively. The wear depths were measured by a profilometer ( $\mathrm{LK} 120 \mathrm{H}, \mathrm{JHJM}, \mathrm{Xi}$ an, China) to evaluate the wear resistance after $30 \mathrm{~min}$.

First-principles calculation was performed based on the density-functional theory and supersoft pseudopotential method. The crystal structure of $\mathrm{NiTi}_{2}$ was constructed to calculate the electronic structure [28]. The CASTEP module in Materials Studio software was implemented to perform generalized gradient approximation (GGA) on the $\mathrm{NiTi}_{2}$ crystal structure and the equation was self-consistently solved by Kohn-Sham. Before the calculation, the unit cell constant of $\mathrm{NiTi}_{2}$ and each atomic lattice were fully relaxed until the unit cell energy converged to a fixed value. The results were not related to spin effects.

\section{Results and Discussion}

Figure 1 depicts the XPS depth profile of the Ti/Ni ion-implanted AM60 alloy. A Ni-rich layer forms on the surface after $\mathrm{Ti} / \mathrm{Ni}$ ion implantation and the ion implantation range is approximately $300 \mathrm{~nm}$. The $\mathrm{Ni}$ atom concentration decreases with the increase in depth. The Ti atom concentration first increases and then decreases with depth. When the depth is $100 \mathrm{~nm}$, the Ti concentration is $25 \%$. A surface oxide layer with a thickness of $150 \mathrm{~nm}$ is present on the surface due to air exposure. The high-resolution XPS spectra of $\mathrm{O}, \mathrm{Mg}$, Ti, and $\mathrm{Ni}$ acquired after various sputtering times are shown in Figure 2. In Figure 2a, the $\mathrm{O}$ peak intensity decreases as the sputtering time increases, and $\mathrm{O}$ is observed at the sputtering times of $0 \mathrm{~min}$ and $15 \mathrm{~min}$. The $\mathrm{Mg}$ intensity increases gradually with sputtering time as shown in Figure 2b. In Figure 2c, the intensity of Ti increases at 15 min and then decreases at $30 \mathrm{~min}$, and the largest concentration of Ti is observed in the middle of the layer. The intensity of Ni decreases with sputtering time as displayed in Figure $2 \mathrm{~d}$. 


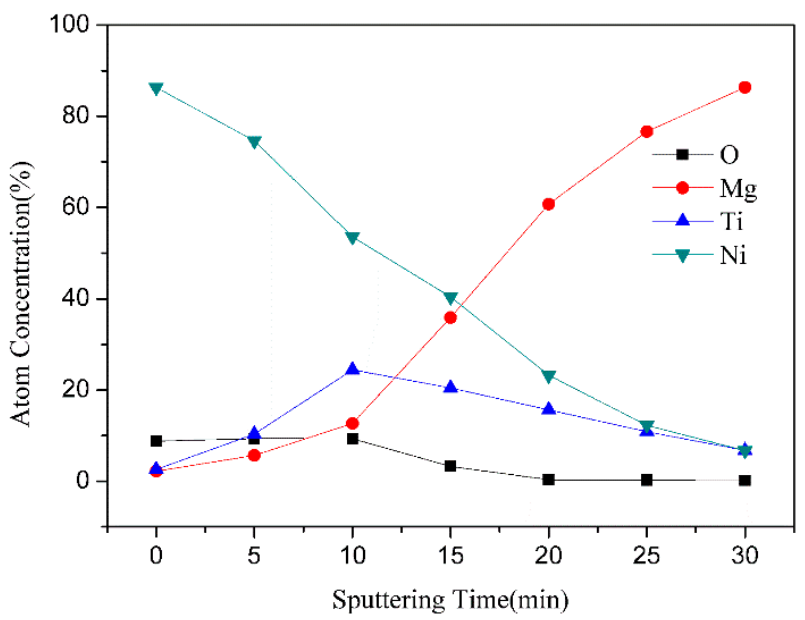

Figure 1. XPS elemental depth profiles acquired from the AM60 alloy after Ti/Ni ion implantation.
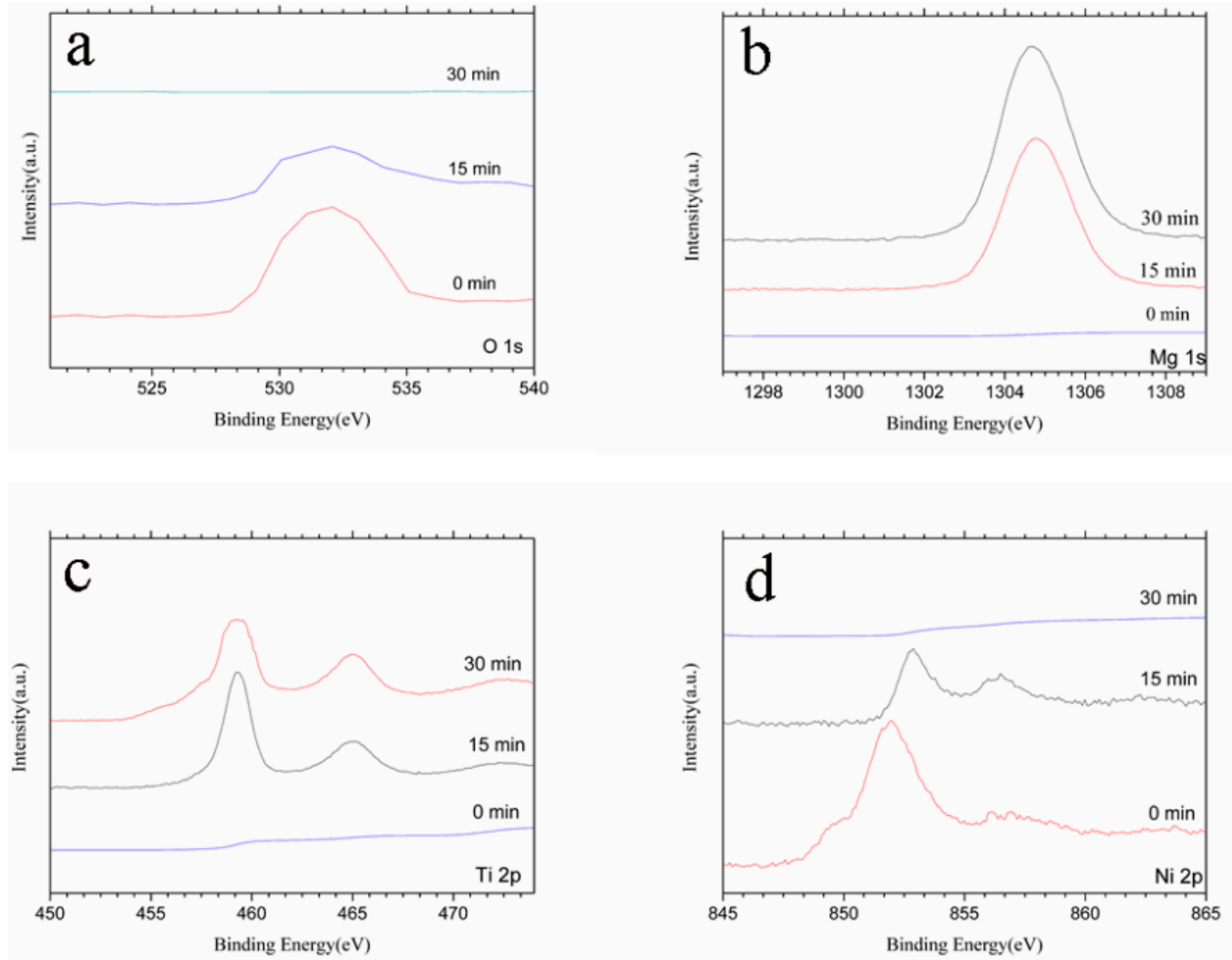

Figure 2. High-resolution XPS spectra of the treated AM60 alloy after various sputtering times: (a) O 1s, (b) Mg 1s, (c) Ti 2p, and (d) Ni 2p.

Figure 3 shows the XRD patterns of different samples. There are $\alpha-\mathrm{Mg}$ and $\mathrm{TiO}_{2}$ on the surface of sample Ti and some $\mathrm{Ni}_{2} \mathrm{O}_{3}$ and $\mathrm{NiTi}_{2}$ on the surface of sample TiNi. Some oxides such as $\mathrm{TiO}_{2}$ and $\mathrm{Ni}_{2} \mathrm{O}_{3}$ are produced after ion implantation and exposure to air. Some $\mathrm{NiTi}_{2}$ compounds are produced during dual ion implantation. It can be speculated that there is a reaction between $\mathrm{Ti}$ and $\mathrm{Ni}$ ions in the process of ion implantation. 


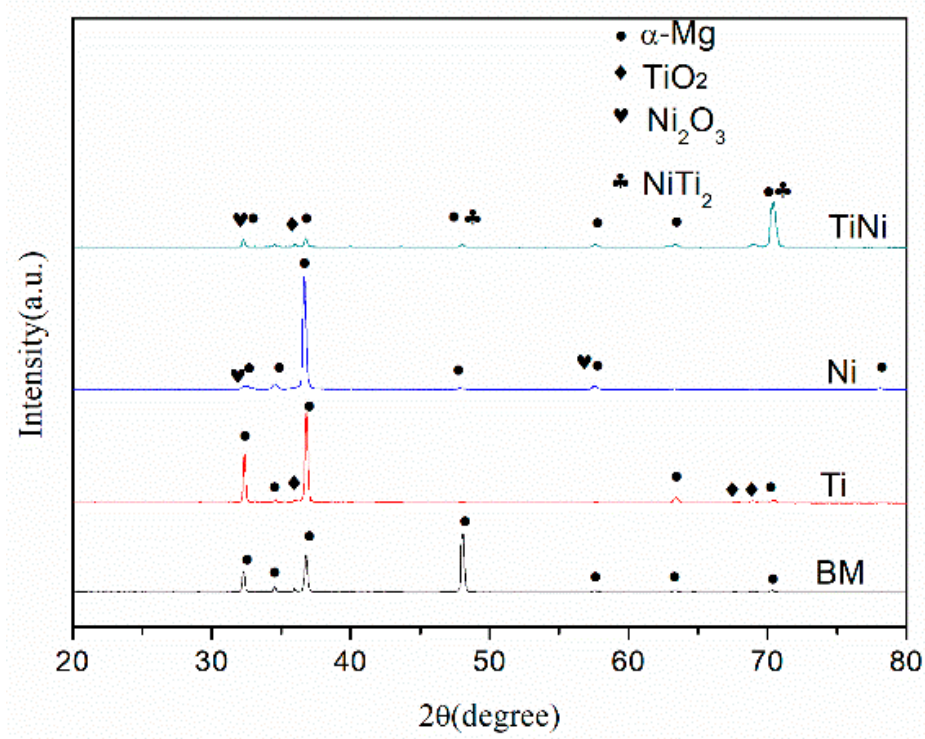

Figure 3. XRD patterns of different samples.

The morphology of the samples after immersion in $3.5 \% \mathrm{NaCl}$ is displayed in Figure 4 . There is little corrosion product on the surface of sample Ti as shown in Figure $4 \mathrm{~b}$, but samples Ni and TiNi were consumed by corrosion. Large amounts of corrosion products are observed on the surfaces of samples Ni and TiNi in Figure 4c,d. According to the Darken-Gurry principle of alloy design, Ti and $\mathrm{Ni}$ are situated all around the Darken-Gurry ellipse with $\mathrm{Mg}$ as the center as shown in Figure 5. Based on Pauling theory, the difference in the electronegativity between two elements indicates the strength of chemical affinity [29]. Electronegativity is the scale of the ability of an element's atom to attract electrons in a compound. The greater the electronegativity of an element, the stronger the ability of its atom to attract electrons in the compound. The electronegativity values of $\mathrm{Ni}, \mathrm{Mg}$ and $\mathrm{Ti}$ are 1.92 , 1.31 and 1.54, respectively. The electronegativity difference between $\mathrm{Ti}$ and $\mathrm{Mg}(0.23)$ is less than that between $\mathrm{Ni}$ and $\mathrm{Mg}(0.61)$. Hence, $\mathrm{Ni}$ and $\mathrm{Mg}$ tend to be coupled, giving rise to electrode reactions and electrochemical corrosion. The main reaction is:

$$
\mathrm{Mg}+\mathrm{Ni}_{2} \mathrm{O}_{3}+3 \mathrm{H}_{2} \mathrm{O}>\mathrm{Mg}(\mathrm{OH})_{2}+2 \mathrm{Ni}(\mathrm{OH})_{2}
$$

According to XRD results acquired from the corrosion products shown in Figure 4d-1, the main products are $\mathrm{Mg}(\mathrm{OH})_{2}$ and $2 \mathrm{Ni}(\mathrm{OH})_{2}$. 


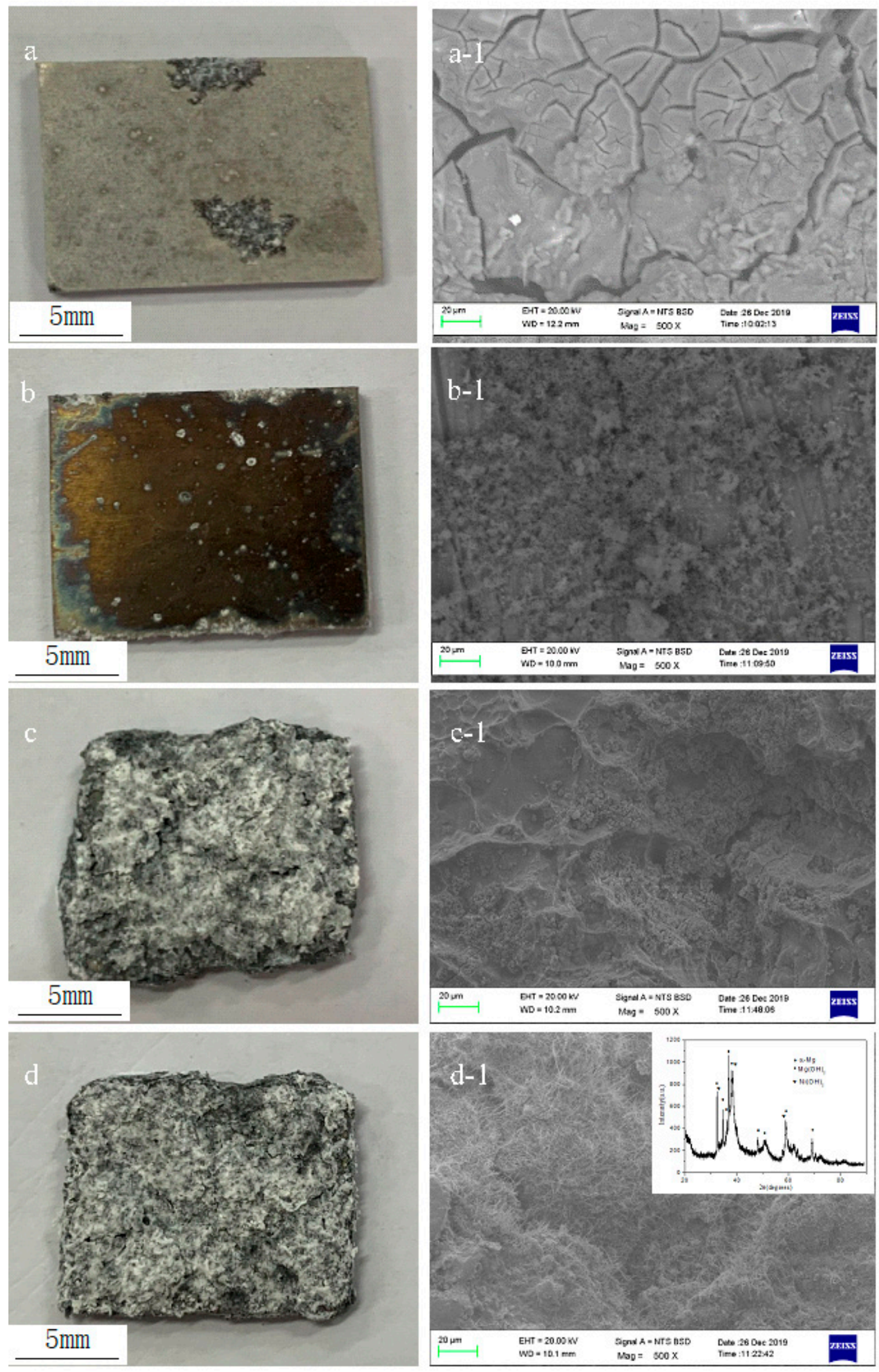

Figure 4. Morphology of the corroded samples: (a) BM, (b) Ti, (c) Ni, (d) TiNi, (i-1) High-magnification SEM pictures, $(I=\mathrm{a}, \mathrm{b}, \mathrm{c}$, and $\mathrm{d})$. 


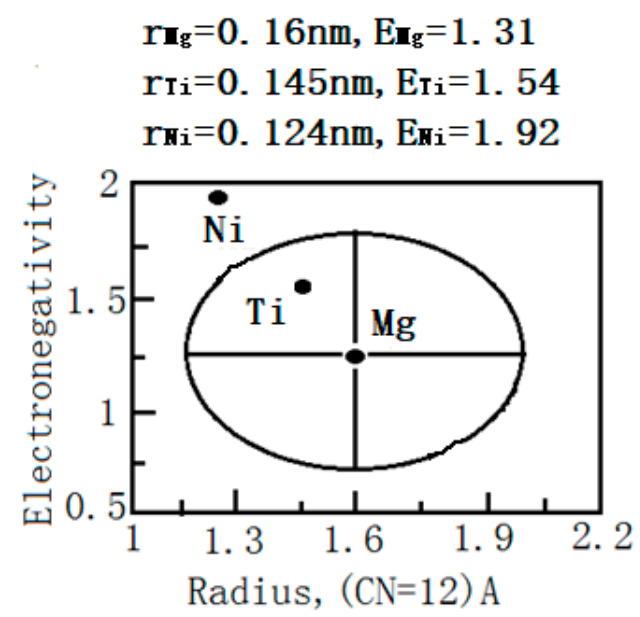

Figure 5. Position of $\mathrm{Ti}$ and $\mathrm{Ni}$ in the Darken-Gurry ellipse of $\mathrm{Mg}$ and electronegativity.

Figure 6 shows the wear depths of different samples. The depth of sample BM is $100.03 \mu \mathrm{m}$ which is larger than those of other samples. The depths of sample Ti and sample Ni are $52.63 \mu \mathrm{m}$ and $40.56 \mu \mathrm{m}$, respectively. In comparison, sample TiNi exhibits the smallest wear depth $(20.26 \mu \mathrm{m})$ and the best wear resistance. The oxide layer on the surface produces microcracks which expand gradually leading to the oxide film eventually cracking and peeling off to form wear debris. The calculation of the worn volume is shown as follows:

$$
w_{\mathrm{d}}=2 \pi r A / p l
$$

where $w_{\mathrm{d}}$ is worn volume $\left(\mathrm{mm}^{3} / \mathrm{mN}\right), r$ is wear radius $(\mathrm{mm}), A$ is profile area of wear mark $\left(\mathrm{mm}^{2}\right), p$ is load $(\mathrm{N}), l$ is wear route $(\mathrm{m}), l=2 \pi \mathrm{rvt}, \mathrm{v}$ is rotation rate $(\mathrm{r} / \mathrm{min})$, and $t$ is wear time $(\mathrm{min})$.

The worn volume results of different samples are shown in Table 1. It can be seen that the worn volume of the BM sample is much larger than the ion implantation samples. The sample TiNi has the smallest worn volume.

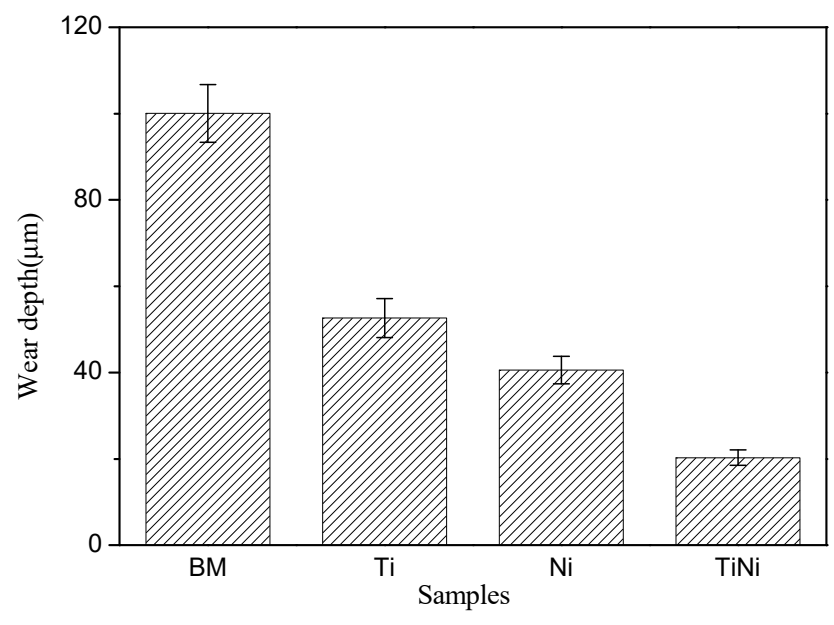

Figure 6. Wear depths of different samples. 
Table 1. Worn volume results of different samples.

\begin{tabular}{cccc}
\hline Samples & Width $(\mathbf{m m})$ & Depth $(\boldsymbol{\mu m})$ & Worn Volume $\left(\mathbf{1 0}^{\mathbf{- 6}} \mathbf{~ m m}^{\mathbf{3}} \cdot \mathbf{m}^{\mathbf{- 1}} \cdot \mathbf{N}^{-\mathbf{1}}\right)$ \\
\hline $\mathrm{BM}$ & 0.62 & 100.03 & 2583 \\
$\mathrm{Ti}$ & 0.54 & 52.63 & 702 \\
$\mathrm{Ni}$ & 0.44 & 40.56 & 440 \\
$\mathrm{TiNi}$ & 0.31 & 20.26 & 155 \\
\hline
\end{tabular}

In order to provide helpful guidance in understanding the wear properties of samples and finding the action of $\mathrm{NiTi}_{2}$ after ion implantation, a first-principles calculation is performed based on the density-functional theory and the supersoft pseudopotential method as aforementioned. $\mathrm{NiTi}_{2}$ has a complex cubic structure. According to Find It, the $\mathrm{NiTi}_{2}$ space group is $\mathrm{Fd}-3 \mathrm{~m}$ (parameter code 227) and $a=b=c=11.3193 \AA$ as displayed in Table 2. Accordingly, a unit cell model is established as shown in Figure $7 \mathrm{a}$, and the electron density map is shown in Figure $7 \mathrm{~b}$. Figure $7 \mathrm{c}$ shows that $\mathrm{d}$ electrons cross the Fermi level in the density of states (DOS) of $\mathrm{NiTi}_{2}$. The electron energy contributing to bonding is mainly concentrated in the range between $-40 \mathrm{eV}$ and $-30 \mathrm{eV}$, and the main source is the valence electron contribution of $\mathrm{Ti}(\mathrm{p}), \mathrm{Ti}(\mathrm{d}), \mathrm{Ni}(\mathrm{d})$. As shown in Figure 7, there are metallic bonds in $\mathrm{NiTi}_{2}$ compounds. It has a high hardness and is difficult to deform under the action of contact stress during the wear test. It can be indicated that $\mathrm{NiTi}_{2}$ does not adhere well to the grinding ring due to the bonding property. Formation of $\mathrm{NiTi}_{2}$ in the dual ion-implanted layer prevents the formation and propagation of microcracks on the surface, and consequently, the wear properties of the sample TiNi are significantly improved after Ti/Ni ion implantation [30].

Table 2. Lattice parameters of $\mathrm{NiTi}_{2}$.

\begin{tabular}{|c|c|c|c|c|c|c|c|c|}
\hline \multirow{2}{*}{ Crystal } & \multirow{2}{*}{$\begin{array}{l}\text { Space } \\
\text { Group }\end{array}$} & \multicolumn{3}{|c|}{ Lattice Parameters } & \multirow{2}{*}{ Elements } & \multicolumn{3}{|c|}{ Atomic Coordinates } \\
\hline & & $a$ & $b$ & $c$ & & $X$ & $Y$ & $Z$ \\
\hline \multirow[t]{3}{*}{$\mathrm{NiTi}_{2}$} & 227 & 11.3193 & 11.3193 & 11.3193 & $\mathrm{Ni}(\mathrm{I})$ & 0.912 & 0.912 & 0.912 \\
\hline & & & & & $\mathrm{Ti}(\mathrm{II})$ & 0.311 & 0 & 0 \\
\hline & & & & & $\mathrm{Ti}$ (II) & 0.125 & 0.125 & 0.125 \\
\hline
\end{tabular}

(a)

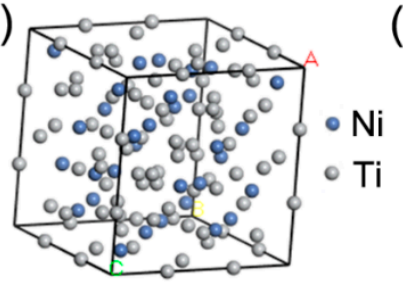

(b)

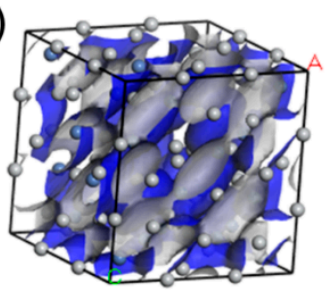

(c)

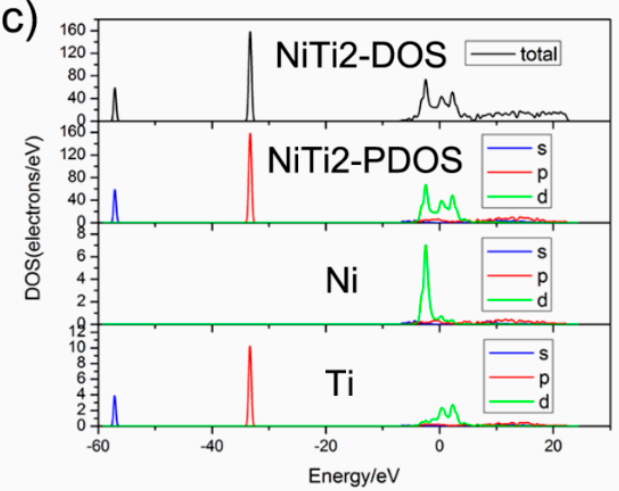

Figure 7. First-principles study of $\mathrm{NiTi}_{2}$ : (a) Unit cell model, (b) Electron density map, and (c) State density maps. 


\section{Conclusions}

A Ni-rich layer forms on the surface after dual $\mathrm{Ti} / \mathrm{Ni}$ ion implantation, and the ion implantation range is approximately $300 \mathrm{~nm}$. There are $\alpha-\mathrm{Mg}, \mathrm{Ni}_{2} \mathrm{O}_{3}$ and $\mathrm{NiTi}_{2}$ in the near-surface after Ti/Ni ion implantation. The corrosion resistance of the $\mathrm{Ni}$ and $\mathrm{Ti} / \mathrm{Ni}$ samples decreases in $3.5 \% \mathrm{NaCl}$. The wear depth measured from the Ti/Ni sample is $20.26 \mu \mathrm{m}$. NiTi 2 does not adhere well to the grinding ring due to the bonding property during the wear test. Comparing the three samples, dual $\mathrm{Ti} / \mathrm{Ni}$ ion implantation into AM60 alloy shows the best wear resistance.

Author Contributions: Conceptualization, J.D. and P.K.C.; methodology, J.D. and Z.L.; software, Z.L. and B.Y.; validation, B.Y.; formal analysis, Q.R.; investigation, Z.L.; resources, J.D.; data curation, B.Y. and Q.R.; writing-original draft preparation, Z.L. and B.Y.; writing—review and editing, J.D. and P.K.C.; visualization, J.D.; supervision, J.D. and P.K.C.; project administration, P.K.C.; funding acquisition, J.D. and P.K.C. All authors have read and agreed to the published version of the manuscript.

Funding: The research was funded by postdoctoral research funding plan in Jiangsu province, grant Number 2018K055C and City University of Hong Kong Strategic Research Grants (SRG), grant number 7005105 and 7005264.

Acknowledgments: The authors would like to thank Xin Tong of City University of Hong Kong for providing assistance in the ion implantation experiments.

Conflicts of Interest: There are no conflicts of interest to declare.

\section{References}

1. Shaha, S.K.; Dayani, S.B.; Xue, Y.N. Improving corrosion and corrosion-fatigue resistance of AZ31B cast mg alloy using combined cold spray and top coatings. Coatings 2018, 8, 443. [CrossRef]

2. Polmear, I.J. Magnesium alloys and applications. Mater. Sci. Technol. 1994, 10, 1-16. [CrossRef]

3. Mukai, T.; Yamanoi, M.; Watanabe, H.; Higashi, K. Ductility enhancement in AZ31 magnesium alloy by controlling its grain structure. Scr. Mater. 2001, 45, 89-94. [CrossRef]

4. Rahmati, M.; Raeissi, K.; Toroghinejad, M.R. Effect of pulse current mode on microstructure, composition and corrosion performance of the coatings produced by plasma electrolytic oxidation on AZ31 Mg alloy. Coatings 2019, 9, 688. [CrossRef]

5. Song, D.; Li, C.; Liang, N.N.; Yang, F.L.; Jiang, J.H.; Sun, J.P.; Wu, G.S.; Ma, A.; Ma, X.L. Simultaneously improving corrosion resistance and mechanical properties of a magnesium alloy via equal-channel angular pressing and post water annealing. Mater. Des. 2019, 166, 107621. [CrossRef]

6. Jian, S.Y.; Ho, M.L.; Shih, B.C. Evaluation of the corrosion resistance and cytocompatibility of a bioactive micro-arc oxidation coating on AZ31 Mg alloy. Coatings 2019, 9, 396. [CrossRef]

7. Cui, X.J.; Lin, X.Z.; Liu, C.H.; Yang, R.S.; Zheng, X.W.; Gong, M. Fabrication and corrosion resistance of a hydrophobic micro-arc oxidation coating on AZ31 Mg alloy. Corros. Sci. 2015, 90, 402-412. [CrossRef]

8. Ignat, S.; Sallamand, P.; Grevey, D.; Lambertin, M. Magnesium alloys laser (Nd: YAG) cladding and alloying with side injection of aluminium powder. Appl. Surf. Sci. 2004, 225, 124-134. [CrossRef]

9. Liu, J.L.; Yu, H.J.; Chen, C.Z.; Weng, F.; Dai, J.J. Research and development status of laser cladding on magnesium alloys: A review. Opt. Lasers. Eng. 2017, 93, 195-210. [CrossRef]

10. Luca, P.; Leonardo, B.C.; Rachele, B.; Alessio, G.S.; Katya, B.; Marjorie, O.; Dabalà, M. Corrosion and mechanical properties of plasma electrolytic oxidation-coated AZ80 magnesium alloy. Mater. Corros. 2019, 70, 2103-2112.

11. Luca, P.; Michele, R.; Alessandro, M.; Katya, B.; Manuele, D. Plasma Electrolytic Oxidation (PEO) as pre-treatment for sol-gel coating on aluminum and magnesium alloys. Surf. Coat. Technol. 2019, 366, 114-123.

12. Wu, G.S.; Jamesh, M.I.; Chu, P.K. Surface design of biodegradable magnesium alloys-A review. Surf. Coat. Technol. 2013, 233, 2-12. [CrossRef]

13. Jamesh, M.I.; Wu, G.S.; Zhao, Y.; McKenzie, D.R.; Bilek, M.M.; Chu, P.K. Electrochemical corrosion behavior of biodegradable Mg-Y-RE and Mg-Zn-Zr alloys in Ringer's solution and simulated body fluid. Corros. Sci. 2015, 91, 160-184. [CrossRef]

14. Feliu, S.; Maffiotte, C.; Samaniego, A.; Galvan, J.C.; Barranco, V. Effect of the chemistry and structure of the native oxide surface film on the corrosion properties of commercial AZ31 and AZ61 alloys. Appl. Surf. Sci. 2011, 257, 8558-8568. [CrossRef] 
15. Zheng, Y.; Zhang, L.B.; Bi, Y.Z. Corrosion behavior of Fe/Zr composite coating on ZK60 Mg alloy by Ion implantation and deposition. Coatings 2018, 8, 261. [CrossRef]

16. Liu, J.; Zheng, Y.; Bi, Y.; Li, Y.; Zheng, Y.F. Improved cytocompatibility of Mg-1Ca alloy modified by Zn ion implantation and deposition. Mater. Lett. 2017, 205, 87-89. [CrossRef]

17. Wan, Y.Z.; Xiong, G.Y.; Luo, H.L.; He, F.; Huang, Y.; Wang, Y.L. Influence of zinc ion implantation on surface nanomechanical performance and corrosion resistance of biomedical magnesium-calcium alloys. Appl. Surf. Sci. 2008, 254, 5514-5516. [CrossRef]

18. Ba, Z.X.; Jia, Y.Q.; Dong, Q.S.; Li, Z.Z.; Kuang, J. Effects of Zr Ion implantation on surface mechanical properties and corrosion resistance of pure magnesium. J. Mater. Eng. Perform. 2019, 28, 2543-2551. [CrossRef]

19. Jin, W.H.; Wu, G.S.; Feng, H.Q.; Wang, W.H.; Zhang, X.M.; Chu, P.K. Improvement of corrosion resistance and biocompatibility of rare-earth WE43 magnesium alloy by neodymium self-ion implantation. Corros. Sci. 2015, 94, 142-155. [CrossRef]

20. Li, Z.C.; Shang, Z.Z.; Wei, X.; Zhao, Q. Corrosion resistance and cytotoxicity of AZ31 magnesium alloy with $\mathrm{N}+$ ion implantation. Mater. Technol. 2019, 34, 730-736. [CrossRef]

21. Jamesh, M.I.; Wu, G.S.; Zhao, Y.; Chu, P.K. Effects of silicon plasma ion implantation on electrochemical corrosion behavior of biodegradable Mg-Y-RE Alloy. Corros. Sci. 2013, 69, 158-163. [CrossRef]

22. Husak, Y.; Solodovnyk, O.; Yanovska, A. Degradation and in vivo response of hydroxyapatite-coated Mg alloy. Coatings 2018, 8, 375. [CrossRef]

23. Liu, H.X.; Xu, Q.; Jiang, Y.H.; Wang, C.Q.; Zhang, X.W. Corrosion resistance and mechanical property of AZ31 magnesium alloy by N/Ti duplex ion implantation. Surf. Coat. Technol. 2013, 228, S538-S543. [CrossRef]

24. Wu, G.S.; Ding, K.J.; Zeng, X.Q.; Wang, X.M.; Yao, S.S. Improving corrosion resistance of titanium-coated magnesium alloy by modifying surface characteristics of magnesium alloy prior to titanium coating deposition. Scr. Mater. 2009, 61, 269-272. [CrossRef]

25. Xie, Z.W.; Chen, Q.; Chen, T.; Gao, X.; Yu, X.G.; Song, H.; Feng, Y.J. Microstructure and properties of nitrogen ion implantation/AlN/CrAlN/MoS2-phenolic resin duplex coatings on magnesium alloys. Mater. Chem. Phys. 2015, 160, 212-220. [CrossRef]

26. Jamesh, M.I.; Wu, G.S.; Zhao, Y.; Jin, W.H.; McKenzie, D.R.; Bilek, M.M.; Chu, P.K. Effects of zirconium and nitrogen plasma immersion ion implantation on the electrochemical corrosion behavior of Mg-Y-RE alloy in simulated body fluid and cell culture medium. Corros. Sci. 2014, 86, 239-251. [CrossRef]

27. Xu, R.Z.; Wu, G.S.; Yang, X.B.; Zhang, X.M.; Wu, Z.W.; Sun, G.Y.; Li, G.Y.; Chu, P.K. Corrosion behavior of chromium and oxygen plasma-modified magnesium in sulfate solution and simulated body fluid. Appl. Surf. Sci. 2012, 258, 8273-8278. [CrossRef]

28. Zhang, Y.; Guo, D.; Geng, H. Characterization of M-class genome segments of Muscovy duck reovirus S14. Virus Res. 2007, 125, 42-53. [CrossRef]

29. Zhang, B.W.; Liao, S.Z. Progress on the theories of solid solubility of alloy. Shanghai Met. 1999, $21,3-9$. (In Chinese)

30. Liu, Y.F.; Zhao, H.Y.; Wang, H.M.; Liu, G.P. Microstructure and wear resistance of laser clad $\mathrm{Ti}_{5} \mathrm{Si}_{3} /\left(\mathrm{NiTi}_{2}+\beta\right.$ $+\mathrm{Ti}_{5} \mathrm{Si}_{3}$ ) composite coating. Mater. Sci. Technol. 2002, 338, 126-132.

(C) 2020 by the authors. Licensee MDPI, Basel, Switzerland. This article is an open access article distributed under the terms and conditions of the Creative Commons Attribution (CC BY) license (http://creativecommons.org/licenses/by/4.0/). 